This is an electronic reprint of the original article. This reprint may differ from the original in pagination and typographic detail.

Author(s): Bennour, Ines; Haukka, Matti; Teixidor, Francesc; Viñas, Clara; Kabadou, Ahlem

Title: $\quad$ Crystal structure and Hirshfeld surface analysis of $[\mathrm{N}(\mathrm{CH} 3) 4]\left[2,2^{\prime}-\mathrm{Fe}(1,7-\right.$-closoC2B9H11)2]

Year: $\quad 2017$

Version:

Please cite the original version:

Bennour, I., Haukka, M., Teixidor, F., Viñas, C., \& Kabadou, A. (2017). Crystal structure and Hirshfeld surface analysis of [N(CH3)4][2,2'-Fe(1,7-closo-C2B9H11)2]. Journal of Organometallic Chemistry, 846, 74-80. https://doi.org/10.1016/j.jorganchem.2017.05.047

All material supplied via JYX is protected by copyright and other intellectual property rights, and duplication or sale of all or part of any of the repository collections is not permitted, except that material may be duplicated by you for your research use or educational purposes in electronic or print form. You must obtain permission for any other use. Electronic or print copies may not be offered, whether for sale or otherwise to anyone who is not an authorised user. 
$\& \quad \$ \$$

$(\& !)) ! \#^{*}+!,-! \cdot / 0$

$1((2$

8912

$? 2$

$* 2$

?A 82

?A 82

82

$12(: \& !:)) ! \# *^{*}+!:,-, !: / 0 !$
$344 \quad 56 \$ \% 47 \$ 4$

$\$ 4: \$ 4 \$ ;<=:=>.: 4 \$: 47: 4 \%$

@ $9 \$^{11 \%}$

Journal of Organometallic Chemistry

$4 \$ \%$

$\$ 54 \$$

$\$ 4 \$ \%$

$4 \$ \% ! 2 \$ 4: \$ 4 \$ ;<=:=>.: 4 \$ \%: 47: 4 \%$ :

! "\#\$! $\%$

\& \$ \$

*18\#.00:A

.BA $>A . .^{*} . B>$

$>!>! A B>00 .: 1$

$>.0 \mathrm{AB}$ !

$>=$ : 


\section{Graphical Abstract}

The two red spots presented on the anionic and cationic HS presentations give an idea about the attendance of two different interactions $\mathrm{H} \cdots \mathrm{H}$ related the same proton, from the $\left[\mathrm{N}\left(\mathrm{CH}_{3}\right)_{4}\right]$ cation, with two different $\mathrm{H}-\mathrm{B}$ vertex from the adjacent anion.

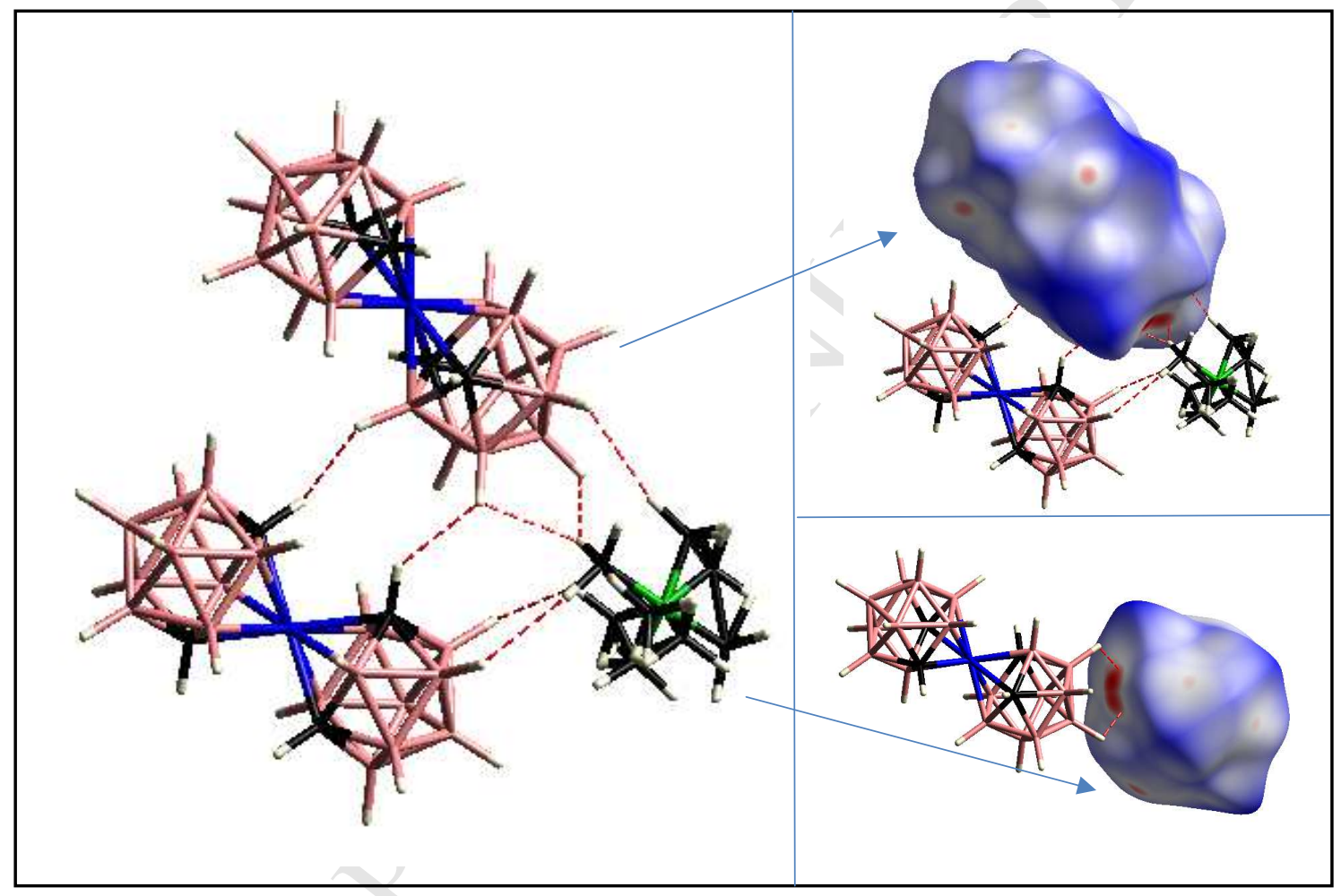




\title{
Crystal Structure and Hirshfeld Surface Analysis of $\left[\mathrm{N}\left(\mathrm{CH}_{3}\right)_{4}\right][2,2$ '- $\mathrm{Fe}(1,7-$
}

\section{closo- $\left.\left.\mathrm{C}_{2} \mathbf{B}_{9} \mathrm{H}_{11}\right)_{2}\right]$}

Ines Bennour, ${ }^{\mathrm{a}, \mathrm{b}}$ Matti Haukka, ${ }^{\mathrm{c}}$ Francesc Teixidor, ${ }^{\mathrm{b}}$ Clara Viñas, ${ }^{\mathrm{b}, *}$ Ahlem Kabadou ${ }^{\mathrm{a}, *}$ [a] Laboratoire de Sciences des Matériaux et de l'Environnement, Faculté des Sciences de Sfax, Université de Sfax, B.P. 1171, 3000 Sfax, Tunisie.E-mail: ahlemkabadou@yahoo.fr [b] Institut de Ciència de Materials de Barcelona (ICMAB-CSIC), Campus U.A.B., 08193, Bellaterra, Barcelona, Spain. E-mail: clara@icmab.es [c] Department of Chemistry, University of Jyväskylä, FIN-40014, Jyväskylä, Finland

\begin{abstract}
This work investigates the meta-ferrabis(dicarbollide) anion that was isolated as salt of tetramethylammonium. The structure of the obtained crystal consisted of discrete [2,2'$\left.\mathrm{Fe}\left(1,7 \text {-closo- } \mathrm{C}_{2} \mathrm{~B}_{9} \mathrm{H}_{11}\right)_{2}\right]^{-}$anions and disordered $\left[\mathrm{N}\left(\mathrm{CH}_{3}\right)_{4}\right]^{+}$cations. The anion had a considerable chemical stability ensured by ionic and Van der Waals interactions. Thus, Hirshfeld surfaces and fingerprint plot were used to visualize, explore, and quantify intermolecular interactions in the crystal lattice of the title compound. This investigation proved that close contacts were dominated by $\mathrm{H} \cdots \mathrm{H}$ interactions.
\end{abstract}

Keyword: meta-carborane, metallabis(dicarbollide), Hirshfeld study, dihydrogen bonds. 


\section{INTRODUCTION}

The study of new compounds formed when main group, $d$ - and $f$-block metals are incorporated in multicage carborane compounds has attracted a great interest due to its high added value in several applications [1]. For this reason, the discovery of metallabis(dicarbollide) complexes by Hawthorne et al. (1965) has been of major importance for borane and organometallic chemistries till the present. The most known metallabis(dicarbollide) complexes are the ones whose general formula is $\left[3,3^{\prime}-\mathrm{M}(1,2-\right.$ $\left.\left.\mathrm{C}_{2} \mathrm{~B}_{9} \mathrm{H}_{11}\right)_{2}\right]^{-}[2]$. These complexes consist of two $\eta^{5}$-carboranyl ligands, nido-[7,8- $\left.\mathrm{C}_{2} \mathrm{~B}_{9} \mathrm{H}_{11}\right]^{2-}$, and an $\mathrm{M}^{3+}$ metal located in between. The $\eta^{5}$-carboranyl ligand possesses $6 \pi$ electrons delocalized in the open pentagonal $\left[\mathrm{C}_{2} \mathrm{~B}_{3}\right]^{2-}$ face similar to the metal-bonding orbitals of the cyclopentadienyl ligand $\left[\mathrm{C}_{5} \mathrm{H}_{5}\right]^{-}$. However, there are several differences between ferrocene and ferra(bisdicarbollide) complexes. In fact, ferrocene is neutral. The hydrogen atoms bonded to the carbons beam out of the center of the aromatic ring. Substituents are largely coplanar with the pentagonal $\mathrm{C}_{5}$ ring and substituents can only be at one plane. Conversely, ferra(bisdicarbollide) is monoanionic where the hydrogen atoms beam out of the center of the icosahedron. The substituent can therefore be located at different planes and are noncoplanar with the pentagonal $\left[\mathrm{C}_{2} \mathrm{~B}_{3}\right]^{2-}$ face.

The interest in these sandwich molecules emanates from the multiple properties that they possess. They have one negative charge distributed throughout the volume of the complex. They are electroactive compounds with a low charge density [3]. They show thermal and chemical stability [1a] and an amphiphilic character [4], as well. This richness explains the many attempts to suggest new metallabis(dicarbollide) derivatives applicable to materials science [5] as an electroactive species in sensors [6] and biosensors [7], as a doping agent in conducting organic polymers [1h], as an extractant of radionuclides from nuclear waste [8], in dye-sensitized solar cells [9] in medicine [10] and in several other fields. 
The study of metallabis(dicarbollide) compounds has specially addressed the $\eta^{5}$-carboranyl ligand derivatives of nido- $\left[7,8-\mathrm{C}_{2} \mathrm{~B}_{9} \mathrm{H}_{11}\right]^{2-}$ but very little is reported on the $\eta^{5}$-carboranyl ligand of the isomer nido-[7,9- $\left.\mathrm{C}_{2} \mathrm{~B}_{9} \mathrm{H}_{11}\right]^{2-}$ that contains the two carbon atoms located at the open $\left[\mathrm{C}_{2} \mathrm{~B}_{3}\right]^{2-}$ face andseparated by one boron atom [11]. Additionally, a survey of the Cambridge Structural Database (CSD) [12] by means of ConQuest [13] on December $12^{\text {th }}$ 2016, revealed fourteen crystal structures of substituted meta-metallabis(dicarbollide) [14] complexes, of which eleven are zwitterion complexes (Co (7 structures), $\mathrm{Ni}$ (2 structures), $\mathrm{Cu}$ and $\mathrm{Fe}$ ) [15], two are monoanionic of $\mathrm{Co}^{3+}$ meta-metallabis(dicarbollide) [16] and one is dianionic with $\mathrm{Ni}^{2+}$ [17]. To our knowledge, there are no reported structures of nonsubstituted monoanionic sandwich meta-ferrabis(dicarbollide).

This work addresses the study of the crystal structure of $\left[\mathrm{N}\left(\mathrm{CH}_{3}\right)_{4}\right]\left[2,2^{\prime}-\mathrm{Fe}(1,7\right.$-closo$\left.\left.\mathrm{C}_{2} \mathrm{~B}_{9} \mathrm{H}_{11}\right)_{2}\right]$ synthesized by complexation reaction of nido-[7,9- $\left.\mathrm{C}_{2} \mathrm{~B}_{9} \mathrm{H}_{11}\right]^{2-}$ with $\mathrm{FeCl}_{2}$. In addition to solving the scarcity of crystal structures of plain $\left[2,2^{\prime}-\mathrm{Fe}\left(1,7-\text { closo- } \mathrm{C}_{2} \mathrm{~B}_{9} \mathrm{H}_{11}\right)_{2}\right]^{\prime}$, our aim was also to check whether the non-adjacent position of the two carbons in $\mathrm{C}_{2} \mathrm{~B}_{3}$ face can influence the structure of the compound by altering the distance between the metal and centroids $\mathrm{C}_{2} \mathrm{~B}_{3}$. We compared the present [2,2'-Fe-1,7-closo- $\left.\left(\mathrm{C}_{2} \mathrm{~B}_{9} \mathrm{H}_{11}\right)_{2}\right]^{-}$and the common [3,3'-Fe-1,2-closo- $\left.\left(\mathrm{C}_{2} \mathrm{~B}_{9} \mathrm{H}_{11}\right)_{2}\right]^{-}$anionic compound. This study is based on the results of

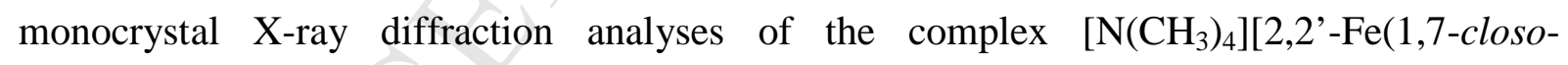
$\left.\left.\mathrm{C}_{2} \mathrm{~B}_{9} \mathrm{H}_{11}\right)_{2}\right]$ and its Hirshfeld surface analysis.

\section{EXPERIMENTAL SECTION}

\section{Synthesis of $\left[\mathrm{N}\left(\mathrm{CH}_{3}\right)_{4}\right]\left[2,2^{\prime}-\mathrm{Fe}\left(1,7-\text {-closo- } \mathrm{C}_{2} \mathrm{~B}_{9} \mathrm{H}_{11}\right)_{2}\right]$}

To a stirring solution of $\left[\mathrm{HN}\left(\mathrm{CH}_{3}\right)_{3}\right]\left[7,9-\right.$ nido- $\left.\mathrm{C}_{2} \mathrm{~B}_{9} \mathrm{H}_{12}\right][18](100 \mathrm{mg}, 0.517 \mathrm{mmol})$ at $0^{\circ} \mathrm{C}$ in dry $\mathrm{THF}(5 \mathrm{ml})$ under nitrogen, $0.78 \mathrm{ml}$ of $n$-BuLi $(1.55 \mathrm{mmol}, 2 \mathrm{M})$ was added dropwise. In another flask and under nitrogen, a suspension of $\mathrm{FeCl}_{2}(196.7 \mathrm{mg}, 1.55 \mathrm{mmol})$ 
in THF ( $5 \mathrm{ml})$ was prepared. Then, the transparent solution of ligand was transferred to the suspension mixture and the reaction mixture stirred under reflux at inert atmosphere overnight. Then, the initially formed Fe(II) complex was converted to an Fe(III) compound by stirring the reaction solution for $2 \mathrm{~h}$ in the presence of air, and the solvent was then removed in vacuum. Extraction was carried out using $5 \mathrm{ml}$ of diethyl ether and $5 \mathrm{ml}$ of $\mathrm{HCl}(0.1 \mathrm{M})$. The organic phase was tried with $\mathrm{MgSO}_{4}$, and after filtering, the solvent was evaporated and the obtained dark green solid dissolved in $3 \mathrm{ml}$ of water and then precipitated using an aqueous solution of $\left[\mathrm{N}\left(\mathrm{CH}_{3}\right)_{4}\right] \mathrm{Cl}$. The dark green solid that precipitated was collected and washed three times with water. Crystallization was done in benzene to give $160.56 \mathrm{mg}$ of

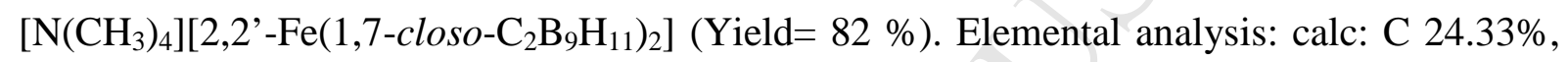
H 8.62\%, N 3.55\%; found: C 24.82\%, H 9.44\%, N 3.44\%. ATR: $v=3018\left(\mathrm{C}_{\mathrm{c}}-\mathrm{H}\right), 2899,2836$ $\left(\mathrm{C}-\mathrm{H}_{(\text {methyl) }}\right), 2535(\mathrm{w}, \mathrm{B}-\mathrm{H}), 1477(\mathrm{C}-\mathrm{N})\left(\right.$ Fig. S1). ${ }^{13} \mathrm{C}\left\{{ }^{1} \mathrm{H}\right\}$ NMR (d $\mathrm{d}_{6}$-acetone): $\delta=-55,18(\mathrm{~s}$, $\left.\mathrm{CH}_{3}\right),-294.34\left(\mathrm{C}_{\mathrm{c}}-\mathrm{H}\right)$ (Fig. $\left.\mathrm{S} 2\right) .{ }^{11} \mathrm{~B}\left\{{ }^{1} \mathrm{H}\right\}-\mathrm{NMR}$ (d $\mathrm{d}_{6}$-acetone): $\delta \quad[\mathrm{ppm}]=-400.9$ (4B, B(6,11,6',11')), -321.9 (2B, B(3,3'), -22.4 (2B), 10.4 (4B), 26.6 (4B), 33.4 (2B) (Fig. S3). Maldi-TOF MS (\%) =: m/z = 321.33 (100) (Fig. S4). Good green crystals suitable for X-ray diffraction were grown in acetone.

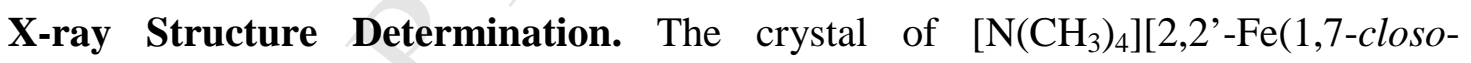
$\left.\mathrm{C}_{2} \mathrm{~B}_{9} \mathrm{H}_{11}\right)_{2}$ ] was immersed in cryo-oil, mounted in a Nylon loop, and measured at a temperature of $170 \mathrm{~K}$. The X-ray diffraction data were collected on a Bruker Kappa Apex II diffractometer using Mo K $\alpha$ radiation $(\lambda=0.71073 \AA$ A $)$. The Denzo/Scapack [19] program package was used for cell refinements and data reductions. The structure was solved by the charge flipping method using SUPERFLIP [20] software. A multiscan absorption correction based on equivalent reflections $(S A D A B S)$ [21] was applied to the data. Structural refinement was carried out using the SHELXL2016 [22] program. The Fe atom of $\left[\mathrm{N}\left(\mathrm{CH}_{3}\right)_{4}\right][2,2$ '- $\mathrm{Fe}(1,7-$ closo- $\left.\mathrm{C}_{2} \mathrm{~B}_{9} \mathrm{H}_{11}\right)_{2}$ ] was located on an inversion center. The carbon atoms of the $\mathrm{NH}_{4}{ }^{+}$counter 
cation were disordered over two sites around a two-fold rotation axis with equal occupancies.

Due to this disorder, the $\mathrm{N}-\mathrm{C}$ and $\mathrm{C}-\mathrm{C}$ distances of the cation were restrained to be similar. Hydrogen atoms were positioned geometrically and constrained to ride on their parent atoms, with $\mathrm{C}-\mathrm{H}=0.98-1.12 \AA, \mathrm{B}-\mathrm{H}=1.12 \AA$, and $\mathrm{U}_{\mathrm{iso}}=1.2-1.5 \mathrm{U}_{\text {eq }}$ (parent atom). The crystallographic details are summarized in Table 1. Crystallographic data (excluding structure factors) for the structures reported in this paper were submitted to the Cambridge Crystallographic Data Centre as supplementary publication no. CCDC 1527813. Copies of the data can be obtained free of charge from www.ccdc.cam.ac.uk/conts/retrieving.html.

The final anisotropic full matrix least squares refinement resulted in a convergence of the $\mathrm{R}$ factor at $0.046, \mathrm{Rw}=0.092$. The crystal structures and packing interactions were depicted using Mercury [23] and DIAMOND [24], respectively.

\section{Hirshfeld surface (HS) analysis}

The Hirshfield surface analyses were carried out using the CrystalExplorer program [25] which accepts a structure input file in the CIF format. HS analysis was performed to identify the types and regions of weak intermolecular interactions, and proportions of these interactions. Molecular HS in crystal structure was constructed from the electron distribution. Distance from the HS to the nearest nucleus inside and outside the surface was marked by the quantities $d_{\mathrm{i}}$ and $d_{\mathrm{e}}$, respectively. $d_{\text {norm }}$ is a normalized contact distance, which was defined in terms of $d_{\mathrm{i}}, d_{\mathrm{e}}$, and the Van der Waals radii of the atoms, as listed in equation (1):

$$
d_{n o r m}=\frac{d_{i}-r_{i}^{v d W}}{r_{i}^{v d W}}+\frac{d_{e}-r_{e}^{v d W}}{r_{e}^{v d W}}
$$

The combination of $d e$ and $d i$ in the form of $2 \mathrm{D}$ fingerprint plot provides an overview of intermolecular contacts in the crystal. The Hirshfeld surfaces mapped with a shape index range of -1.0 to $1.0 \AA, d_{\text {norm }}$ range of -0.5 to $1.5 \AA$, and full fingerprint plot can be created. 


\section{RESULTS AND DISCUSSIONS}

\subsection{Crystal structure}

Good crystals of $\left[\mathrm{N}\left(\mathrm{CH}_{3}\right)_{4}\right]\left[2,2^{\prime}-\mathrm{Fe}\left(1,7 \text {-closo- } \mathrm{C}_{2} \mathrm{~B}_{9} \mathrm{H}_{11}\right)_{2}\right]$ suitable for X-raydiffraction were grown from an acetone solution at $-4^{\circ} \mathrm{C}$. The title compound was solved in a monoclinic system, $\mathrm{C} 2 / \mathrm{c}$ space group with four formula units in unit cell ( $\mathrm{Z}=4$ ) (Fig. S5). The Fe atoms lied on the $4(\mathrm{~d})(1 / 4,1 / 4,1 / 2)$ sites, surrounded by four carbon atoms and six boron atoms in the same Wyckoff positions $8(\mathrm{f})$. The $\mathrm{N}$ atoms occupied the 4(e) $(1 / 2, \mathrm{y}, 1 / 4)$ sites, connected by four carbon atoms with 8 (f) positions and the $\mathrm{H}$ atoms (by implication) the $8(\mathrm{f})(\mathrm{x}, \mathrm{y}, \mathrm{z})$ sites.

Noticeable is the packing of $\left[\mathrm{N}\left(\mathrm{CH}_{3}\right)_{4}\right]\left[2,2^{\prime}\right.$ - $\left.\mathrm{Fe}\left(1,7-\text { closo- } \mathrm{C}_{2} \mathrm{~B}_{9} \mathrm{H}_{11}\right)_{2}\right]$ along the $c$ axis, shown in Fig. S6, in which the anionic and cationic layers pack one on top of each other. The $\mathrm{B} / \mathrm{C}$ assignments in the cage are well-established from $\mathrm{B}-\mathrm{C}$ and $\mathrm{B}-\mathrm{B}$ distances ${ }^{26}$ and displacement ellipsoid behavior, and do not appear to be disordered. The asymmetric unit of the studied crystal consisted of half a [2,2'-Fe(1,7-closo- $\left.\left.\mathrm{C}_{2} \mathrm{~B}_{9} \mathrm{H}_{11}\right)_{2}\right]^{-}$anion (Fig. 1) located on

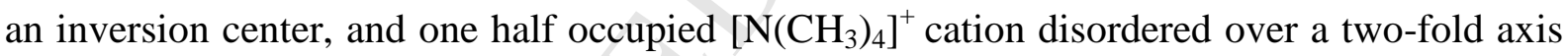
as displayed in Fig. S7. For one cation, the static disorder was a simple 50:50 split over two sites. Tetramethylammonium chloride was the salt used in this synthesis to produce the quaternary ammonium cation as a counterion. The methyl groups were tetrahedrally arranged around the central $\mathrm{N}$ atom. The 11-vertex polyhedral present in one cage of the anion part was formed of triangulated faces. In addition, in the anion part, the iron ion was coordinated by four carbon and six boron atoms (Fig. 2). The Fe atom was displayed as an inversion center between the two cages of nido $\mathrm{C}_{2} \mathrm{~B}_{9}$ clusters. This central metal atom, in oxidation state $(+\mathrm{III})$, is $\eta^{5}$ bonded to two dicarbollide ligands, each contributing with two negative charges. It was localized between the two open pentagonal faces $C_{2} B_{3}$ (Fig. 2b). The planar bonding faces of the two dicarbollide ligands in our compound were nearly parallel (Fig. 2a). Moreover, the 
angles through the metal and between two opposite atoms (like $\mathrm{C}(1)-\mathrm{Fe}-\mathrm{C}(1)^{\mathrm{a}}$, a : 1/2-x, 1/2$\mathrm{y}, 1-\mathrm{z})$ were $180^{\circ}$. The bond lengths at each planar pentagonal face were four B-C (1.698(3)1.706(3) $\AA$ ) and one B-B (1.792(3) $\AA$ ). The three iron-boron interatomic distances were Fe$\mathrm{B}(3): 2.100(2) \AA, \mathrm{Fe}-\mathrm{B}(11): 2.131(2) \AA$, and $\mathrm{Fe}-\mathrm{B}(6): 2.111(2)$ respectively, while the $\mathrm{Fe}-\mathrm{C}_{\mathrm{c}}$ distances average were $2.097 \AA$.

\subsection{H $\cdots H$ short interaction study}

As shown by Fig. S8, each anion has self-interactions and anion-cation hydrogen interactions. There are eight possible self-interactions of the anion [2,2'-Fe(1,7-closo$\left.\left.\mathrm{C}_{2} \mathrm{~B}_{9} \mathrm{H}_{11}\right)_{2}\right]^{-}$as presented in Fig. S8a The same figure demonstrates the presence of two different distances of the intermolecular bond $\mathrm{H}^{\cdots} \mathrm{H}$ for the interactions $\mathrm{C}(1)-\mathrm{H} \cdots \mathrm{H}-\mathrm{B}$ and $\mathrm{C}(7)-\mathrm{H} \cdots \mathrm{H}-\mathrm{B}$ equal to $2.31 \AA$ and $2.24 \AA$, respectively. This result is due to the fact that these interactions are related to (i) the acidic character of $\mathrm{C}_{\mathrm{c}} \cdots \mathrm{H}$ where the proton has a positive charge and (i) the hydride character of the B-H vertex where the proton has a negative charge (according to Pauling scale for $\chi_{H}=2.20$, for the $\chi_{B}=2.04$ and for the $\chi_{C}=2.55$ ) [27]. On the other side, the two independent labeled ions are aggregated through $14 \mathrm{C}_{[\mathrm{N}(\mathrm{CH} 3) 4]+}-\mathrm{H} \cdots \mathrm{H}-\mathrm{B}$ interactions by virtue of the donor character of the proton of $\left[\mathrm{N}\left(\mathrm{CH}_{3}\right)_{4}\right]^{+}$in front of the acceptor character of the proton connected to the boron (Fig. S8b). C-H of six different disordered $\left[\mathrm{N}\left(\mathrm{CH}_{3}\right)_{4}\right]^{+}$interact with the $\mathrm{H}-\mathrm{B}$ of the center anion as follows: The two first

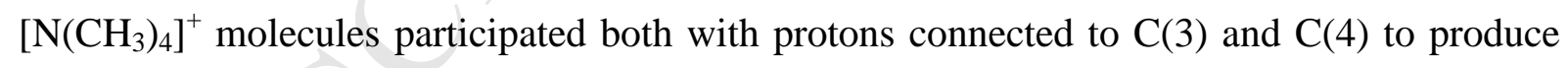
$\mathrm{H} \cdots \mathrm{H}$ interactions equal to $2.25 \AA$ and $2.35 \AA$, respectively. Although the other two cations participate with the same carbons $(\mathrm{C}(3)$ and $\mathrm{C}(4))$, the distance of $\mathrm{C}(3)-\mathrm{H} \cdots \mathrm{H}-\mathrm{B}$ becomes longer $(2.37 \AA)$. On the other hand, the two remaining $\left.\left[\mathrm{N}_{(\mathrm{CH}}\right)_{4}\right]^{+}$cations participate by

different $\mathrm{C}-\mathrm{H}$ vertex. The first one is the $\mathrm{C}(6)-\mathrm{H}$; where it presents $\mathrm{H} \cdots \mathrm{H}$ equal to $2.39 \AA$ for both different $\left.\left[\mathrm{N}_{(\mathrm{CH}}\right)_{4}\right]^{+}$cations. The second proton that is connected to $\mathrm{C}(5)$ presents a very 
different behavior, and it interacts at the same time with two H-B from different vertices which present distances $\mathrm{C}(5)-\mathrm{H} \cdots \mathrm{H}-\mathrm{B}(1)=2.24 \AA$ and $\mathrm{C}(5)-\mathrm{H} \cdots \mathrm{H}-\mathrm{B}(2)=2.32 \AA$.

\subsection{Hirshfeld surface (HS) study:}

In addition to the electrostatic contribution, the existing intermolecular $\mathrm{C}-\mathrm{H} \cdots \mathrm{H}-\mathrm{B}$ interactions also have an important role in the stabilization of this molecule. This was studied and confirmed by Hirshfeld surfaces (HS) analysis using the crystal explorer program. The HS can present the $d_{\text {norm }}$ figure type in which contacts with distances equal to the value of Van der Waals radii are represented by a white color, and the contact distance with shorter values than Van der Waals are revealed by the red color, while the distances longer than Van der Waals are presented as blue color [28]. Also, the HS illustrated in the shape index figure reveals the character of proton present in each unity; the red concavity is related to the presence of an acceptor proton, while the blue convexity is related to the presence of a donor proton.

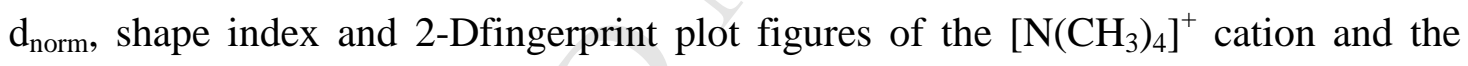
[2,2'- $\left.\mathrm{Fe}\left(1,7-\text { closo- } \mathrm{C}_{2} \mathrm{~B}_{9} \mathrm{H}_{11}\right)_{2}\right]^{-}$anion are presented in Fig. 3. For the cation part, to generate HS, the two orientations with them partial occupancies are included. The molecular HS of anion and cation unity in $\left[\mathrm{N}\left(\mathrm{CH}_{3}\right)_{4}\right]\left[2,2^{\prime}-\mathrm{Fe}\left(1,7-\text { closo- }-\mathrm{C}_{2} \mathrm{~B}_{9} \mathrm{H}_{11}\right)_{2}\right]$ structure is mapped over a $\mathrm{d}_{\text {norm }}$ range from -0.196 to $1.246 \AA$ and -0.195 to $1.335 \AA$, respectively. Visual inspection of fingerprint plots reveals that the anion and cation have nearly the different fingerprint plots evince in the distribution of interaction (related $d e$ and $d i$ values) of the ions in asymmetric unit. The diffuse blue region manifested as a scattered point in the fingerprint plot is related to $\mathrm{H} \cdots \mathrm{H}$ contacts, which account for $100 \%$ of the total Hirshfeld surface area of each $\left[\mathrm{N}\left(\mathrm{CH}_{3}\right)_{4}\right]\left[2,2^{\prime}\right.$ - $\left.\mathrm{Fe}\left(1,7 \text {-closo- } \mathrm{C}_{2} \mathrm{~B}_{9} \mathrm{H}_{11}\right)_{2}\right]$ unity where $\left[\mathrm{N}\left(\mathrm{CH}_{3}\right)_{4}\right]^{+}$and $\left[2,2^{\prime}\right.$ - $\mathrm{Fe}(1,7$-closo$\left.\left.\mathrm{C}_{2} \mathrm{~B}_{9} \mathrm{H}_{11}\right)_{2}\right]^{-}$show a shorter $\mathrm{H} . . . \mathrm{H}$ interaction. The shortest close contacts between hydrogen atoms have a distance of approximately $2.43 \AA$ (notice that the Van der Waals radium for the 
hydrogen atoms is $1.2 \AA$ ). For $\left[2,2^{\prime}-\mathrm{Fe}\left(1,7 \text {-closo- } \mathrm{C}_{2} \mathrm{~B}_{9} \mathrm{H}_{11}\right)_{2}\right]^{-}$, complementary regions are visible in the 2-D fingerprint plots where one anion acts as a donor $(d e<d i)$ and the other as an acceptor $(d e>d i)$ [29]. Therefore, the 2-D fingerprint plots of cation $\left[\mathrm{N}\left(\mathrm{CH}_{3}\right)_{4}\right]^{+}$had an asymmetric distribution in $d e$ and $d i$; which indicates that the cation protons displayed a donor character $(d e<d i)$.

The $d_{\text {norm }}$ (normalized contact distance, see Equation1) surfaces reveal the close contacts of hydrogen bond donors and acceptors, and other contacts. The $\mathrm{d}_{\text {norm }}$ mapped on HS for visualizing the intermolecular interactions in the crystal lattice of $\left[\mathrm{N}\left(\mathrm{CH}_{3}\right)_{4}\right]^{+}$and $\left[2,2^{\prime}-\right.$ $\left.\mathrm{Fe}\left(1,7 \text {-closo- } \mathrm{C}_{2} \mathrm{~B}_{9} \mathrm{H}_{11}\right)_{2}\right]^{-}$is shown in Fig. 3a and Fig. 3c, respectively. It demonstrates that the large circular depressions are visible on the front and back views of the surface of both analyzed unities with two forms: (i) convex form as labeled (1) and (4) relative to acceptor interaction $\mathrm{C}-\mathrm{H} \cdots \mathrm{H}$ and (ii) convex form indexed as (3) characterizes donor $\mathrm{B}-\mathrm{H} \cdots \mathrm{H}$ interaction in the structure. The $\mathrm{H} \cdots \mathrm{H}$ interactions are also evidenced in shape index by a red concave region around the acceptor hydrogen atom (labeled as (5) in Fig. 3e) that confirms the hydride character of the hydrogen connected to the Boron in cluster anion. Fig. $3 \mathrm{~b}$ and $3 \mathrm{e}$ present a complementary blue convex region around the donor hydrogen atoms (indexed as 2 and 6, respectively); which is a consequence of the acidic character of $\mathrm{C}-\mathrm{H}$ characterizing the $\mathrm{C}_{[\mathrm{N}(\mathrm{CH} 3) 4]+}-\mathrm{H} \cdots \mathrm{H}$ and $\mathrm{C}_{\mathrm{c}}-\mathrm{H} \cdot \cdots \mathrm{H}$ interactions.

The two red spots on the HS presentations in Fig. 3a and Fig. $3 b$ show the attendance of two different interactions $\mathrm{H} \cdots \mathrm{H}$ related to the same proton, from the $\left[\mathrm{N}\left(\mathrm{CH}_{3}\right)_{4}\right]^{+}$cation, with two different H-B vertex from the adjacent anion. This explains the orientation of ions in the cell as confirmed by Fig. 4.

\subsection{Comparison}

The crystal structure of the dianionic ortho-ferrabis(dicarbollide) complex was synthesized by Hawthorne et al.[30]. A comparison of the dianionic [3,3'-Fe(1,2-closo- 
$\left.\left.\mathrm{C}_{2} \mathrm{~B}_{9} \mathrm{H}_{11}\right)_{2}\right]^{-}$with the new monoanionic [2,2'-Fe(1,7-closo- $\left.\left.\mathrm{C}_{2} \mathrm{~B}_{9} \mathrm{H}_{11}\right)_{2}\right]^{-}$reported in this paper was made to check the influence of the position of carbon atoms as well as the charge in the crystals. In fact, both ferrabis(dicarbollide) isomers crystallize in the same unit cell with different space group as present in Table 2. In both structures, the presence of a disordered salt molecule in the crystal structures was observed, knowing that the tetramethylammonium is the cation in both compounds. Consequently, both isomers keep the same distance between the iron atom and the two pentagonal faces, but the volume of this space in metaferrabis(dicarbollide) compound was slightly increased. This small difference was observed through a small shift of values of Fe-C and Fe-B distances as presented in Table 3. The $\mathrm{y}^{5}$ coordinate and the electronic factors made the iron similarly distant between the two opposite nido-carborane cages.

The synthesis of metallabis(dicarbollides) using the iron as a metal with carbons separated by one boron atom increases the stability of this ferrabis(dicarbollide) by a thermal factor.

\section{CONCLUSIONS}

The first crystal structures of plain $\left[2,2^{\prime}-\mathrm{Fe}\left(1,7-\text { closo }-\mathrm{C}_{2} \mathrm{~B}_{9} \mathrm{H}_{11}\right)_{2}\right]^{-}$anion where the two carbons of the face in $\mathrm{C}_{2} \mathrm{~B}_{3}$ are in non-adjacent positions was reported as tetramethylammonium salt. The structure of the new crystal consisted of discrete $\left[2,2^{\prime}-\mathrm{Fe}(1,7-\right.$ closo- $\left.\left.\mathrm{C}_{2} \mathrm{~B}_{9} \mathrm{H}_{11}\right)_{2}\right]^{-}$anions and disordered $\left[\mathrm{N}\left(\mathrm{CH}_{3}\right)_{4}\right]^{+}$cations. The ferrabis(dicarbollide) complexes of both isomers, $\left[\mathrm{N}\left(\mathrm{CH}_{3}\right)_{4}\right]\left[3,3^{\prime}-\mathrm{Fe}\left(1,2 \text {-closo- } \mathrm{C}_{2} \mathrm{~B}_{9} \mathrm{H}_{11}\right)_{2}\right]$ and $\left[\mathrm{N}\left(\mathrm{CH}_{3}\right)_{4}\right]\left[2,2^{\prime}\right.$ $\mathrm{Fe}\left(1,7 \text {-closo- } \mathrm{C}_{2} \mathrm{~B}_{9} \mathrm{H}_{11}\right)_{2}$, crystallize in the monoclinic system but in different space groups, $\mathrm{P} 2_{1} / \mathrm{C}$ and $\mathrm{C} 2 / \mathrm{C}$, respectively. Hirshfeld surface studies were done for $\left[\mathrm{N}\left(\mathrm{CH}_{3}\right)_{4}\right]\left[2,{ }^{\prime}\right.$ - $\mathrm{Fe}(1,7-$ closo- $\left.\left.\mathrm{C}_{2} \mathrm{~B}_{9} \mathrm{H}_{11}\right)_{2}\right]$ complex. The crystallographic structure of the anionic [2,2'-Fe(1,7-closo$\left.\left.\mathrm{C}_{2} \mathrm{~B}_{9} \mathrm{H}_{11}\right)_{2}\right]^{-}$clusters was ensured by ionic and $\mathrm{H} \cdots \mathrm{H}$ short interaction. 
Thus, Hirshfeld surfaces and fingerprint plot were used to visualize, explore, and quantify intermolecular interactions in the crystal lattice of the title compound. This investigation proved that close contacts were also dominated by $\mathrm{H} \cdots \mathrm{H}$ interactions.

\section{Acknowledgements}

This work has been supported by the Spanish Ministerio de Economía y Competitividad (CTQ2013-44670-R), and the Generalitat de Catalunya (2014/SGR/149). I. Bennour is enrolled in the $\mathrm{PhD}$ program of the University of Sfax. 


\section{REFERENCES}

[1] a) J. Plesek, Chem. Rev. 92 (1992) 269-278; b) R.N. Grimes in Carboranes, Carboranes, $3^{\text {rd }}$ Ed., Elsevier Inc. 2016; c) R. N. Grimes, J. Organomet. Chem. 747 (2013) 4-15; d) S.V. Timofeev, I.B. Sivaev, E.A. Prikaznova, V.I. Bregadze, J. Organomet. Chem. 751 (2014) 221250; e) L. Deng, Z.W. Xie, Coord. Chem. Rev. 251 (2007) 2452-2476; f) I.B. Sivaev, V.I. Bregadze, J. Organomet. Chem. 614 (2000) 27-36; g) I.B. Sivaev, V.I. Bregadze, Collect. Czech. Chem. Commun. 64(5), (1999), 783-805. h) R. Núñez. I. Romero, F. Teixidor, C. Viñas, Chem. Soc. Rev. 45 (2016) 5147-5173; i) J. Cabrera-González, V. Sánchez-Arderiu, C. Viñas, T. Parella, F. Teixidor, R. Núñez, Inorg. Chem. 55 (2016) 11630-11634; j) N.S. Hosmane, J.A. Maguire, Comprehensive Organometallic Chemistry III, $3^{\text {th }}$ Ed., 2007, 175264; k) H.W. Roesky, S. Singh, K.K.M. Yusuff, J. A. Maguire, N.S. Hosmane, Chem. Rev. 106(9) (2006) 3813-3843.

[2] M.F. Hawthorne, T.D. Andrews, Chem. Commun. 19 (1965) 443-444.

[3] C. Masalles, J. Llop, C. Viñas, F. Teixidor, Adv. Mater. 14(11) (2002) 826-829.

[4] a) R.N. Grimes, Advanced Inorganic Chemistry, $6^{\text {th }}$ Ed., 1999, 143; b) P. Bauduin, S. Prevost, P. Farras, F. Teixidor, O. Diat, T. Zemb, Angew. Chem. Int. Ed. 50 (2011) 52985300; c) M. Uchman, V. Dordovi, Z. Tosner, M. Pavel, Angew. Chem. Int. Ed. 54 (2015) 14113-14117.

[5] a) M.F. Hawthorne, J.I. Zink, J.M. Skelton, M.J. Bayer, C. Liu, E. Livshits, R. Baer, D. Neuhauser, Am. Assoc. Adv. Sci. Pub. 303 (2004) 1849; b) A. K. Singh, A. Sadrzadeh, B.I. Yakobson, J. Amer. Chem. Soc. 132(40) (2010) 14126-14129; c) J. Zhang, Z. Xie, Acc. Chem. Res. 47(5) (2014) 1623-1633; d) S.M. Gao, N.S. Hosmane, Russ. Chem. Bull. 63(4) (2014) 788-810; e) C. Viñas, F. Teixidor, R. Nuñez, Inorg. Chim. Acta. 409 (2014) 12-25.

[6] a) A.L. Stoica, C. Viñas, F. Teixidor, Chem. Commun. (2008) 6492-6494; b) A. L. Stoica, C. Viñas, F. Teixidor, Chem. Commun. (2009) 4988-4990. 
[7] a) T. Garcia-Mendiola, V. Bayon-Pizarro, A. Zaulet, I. Fuentes, F. Pariente, F. Teixidor,

C. Viñas, E. Lorenzo, Chem. Sci. 7 (2016) 5786-5797; b) I. Grabowska, A. Stachyra, A. Gora-Sochacka, A. Sirko, A.B. Olejniczak, Z.J. Lesnikowski, J. Radecki, H. Radecka, Biosens Bioelectron. 51 (2014) 170-176; c) R. Ziolkowski, A.B. Olejniczak, L. Gorski, J. Janusik, Z.J. Lesnikowski, E. Malinowska, Bioelectrochemistry. 87 (2012) 78-83.

[8] a) C. Viñas, S. Gómez, J. Bertrán, F. Teixidor, J. Dozol, H. Rouquette, Chem. Commun. (1998), 191-192; b) C. Viñas, S. Gómez, J. Bertrán, F. Teixidor, J. Dozol, H. Rouquette, Inorg. Chem. 37 (1998) 3640-3643; c) B. Grüner, J. Plesek, J. Báca, I. Cisarová, J. Dozol, H. Rouquette, C. Viñas, P. Selucký, J. Rais, New J. Chem. 26 (2002) 1519-1527; d) M. Bubenikova, P. Selucky, J. Rais, B. Gruner, P. Svec, J. Radioanal. Nucl. Chem. 293 (2012) 403-408. e) B. Gruner, P. Svec, Z. Hajkova, I. Cisarova, J. Pokorna, J. Konvalinka, Pure Appl. Chem. 84 (2012) 2243-2262.

[9] T.C. Li, A.M. Spokoyny, C. She, O.K. Farha, C.A. Mirkin, T.J. Marks, J.T. Hupp J. Am. Chem. Soc. 132 (2010) 4580-4582.

[10] a) Z. Lesnikowski, J. Med. Chem. 59(17) (2016) 7738-7758; b) M. Scholz, E. HeyHawkins, Chem. Rev. 111(11) (2011) 7035-7062; c) P. Cígler, M. Kožíšek, P. Řezáčová, J. Brynda, Z. Otwinowski, J. Pokorná, J. Plešek, B. Grüner, L. Dolečková-Marešová, M. Máša, J. Sedláček, J. Bodem, H. G. Kräusslich, V. Král, J. Konvalinka, Proc. Natl. Acad. Sci. U.S.A. 102(43) (2005) 15394-15399; e) J. F. Valliant, K. J. Guenther, A. S. King, P. Morel, P. Schaffer, O. O. Sogbein, K. A. Stephenson, Coord. Chem. Rev. 232(1-2) (2002) 173-230.

[11] V.L. Shirokii, A.A. Erdman, Z.P. Zubreichuk, N.A. Maier, Y.A. Oldekop, Zh. Obshch. Khim+. 53(4) (1983) 951-952.

[12] a) CSD version 5.38, November 2016 updates; b) J. Bruno, J.C. Cole, P.R. Edgington, M. Kessler, C.F. Macrae, P.M. Cabe, J. Pearson, R. Taylor, Acta Crystallogr. B58 (2002) 389397. 
[13] F.H. Allen, Acta Crys. B 58 (2002) 380.

[14] BOGQIX, ETCBNI, PUGRUE, PUGSAL, RAGPOE, RUJNEP, RUJNIT, VETLOV, VETLOV10, YAHLIC, YAHLOI, YAHLUO, YAHMAU, YAHMEZ.

[15] a) B. Grüner, I. Cisarová, A. Franken, J. Plešek, Tetrahedron: Asymmetry. (1998) 79-88;

b) J. Plešek, A. Franken, R. Fröhlich, Collect. Czech. Chem. Commun. 62 (1997) 1070-1079;

c) M.F. Hawthorne, A. Varadarajan, C.B. Knobler, S. Chakrabarti, R.J. Paxton, B.G. Beatty, F.L. Curtis, J. Am. Chem. Soc. 112 (1990) 5365-5366; d) A. Varadarajan, S. E. Johnson, F. A. Gomez,.S. Chakrabarti, C. B. Knobler, M. F. Hawthorne, J. Am. Chem. Soc. 114 (1992) 9003-9011.

[16] a) C. Viñas, S. Gomez, J. Bertran, J. Barron, F. Teixidor, J.F. Dozol, H. Rouquette, R. Kivekäs, R. Sillanpää, J. Organomet. Chem. 581 (1999) 188-193; b) J. Plešek, A. Franken, R. Fröhlich, Collect. Czech. Chem. Commun. 62 (1997) 57-61.

[17] R.M. Wing, J. Am. Chem. Soc. 92 (5) (1970) 1187-1190.

[18] M.F. Hawthorne, D. C. Young, P. M. Garrett, D. A. Owen, S. G. Schwerin, F. N. Tebbe, P. A. Wegner, J. Am. Chem. Soc. 90(4) (1968) 862-868.

[19] a) Z. Otwinowski, W. Minor, Processing of X-ray Diffraction Data Collected in Oscillation Mode, Academic Press, New York, pp. 307-326, 1997; b) In Methods in Enzymology, Volume 276, Macromolecular Crystallography, Part A, Carter, C. W., Sweet, J., Eds.; Academic Press: New York, USA, 1997; pp 307-326.

[20] L. Palatinus, G. Chapuis, J. Appl. Cryst. 40 (2007) 786-790.

[21] G. M. Sheldrick, SADABS - Bruker Nonius scaling and absorption correction -, Bruker AXS, Inc.: Madison, Wisconsin, USA, 2012.

[22] G. M. Sheldrick, Acta Cryst. (2015) C71, 3-8. 
[23] C.E. Macrae, I.J. Bruno, J.A. Chisholm, P.R. Edgington, P. McCabe, E.Pidcock, L.

Rodriguez-Monge, R.Taylor, J. Van de Streek, P. A. Wood, J. Appl. Cryst. 41 (2008) 466470.

[24] K. Brandenburg, Diamond Version2.0 Impact Gbr, Bonn, Germany, 1998.

[25] S.K. Wolff, D.J. Grimwood, J.J.McKinnon, D. Jayatilaka, M.A. Spackamn, Crystal explorer 3.0, University of Western Australia, Perth, 2007.

26 A. McAnaw, G. Scott, L. Elrick, G.M. Rosair, A. J. Welch, Dalton Trans. 42 (2013) 645664.

[27] E.J. Juarez-Perez, R. Nuñez, C. Viñas, R. Sillanpää, F. Teixidor, Eur. J. Inorg. Chem. (2010) 2385-2392.

[28] M. A. Spackman, D. Jayatilaka, Cryst. Eng. Commun. 11 (2009) 19-32.

[29] S. K. Seth, G. ChMaity, T. Kar, J. Mol Struct. 1000 (2011) 120-126.

[30] H.C. Kang, S.S. Lee, C.B. Knobler, M.F. Hawthorne, Inorg. Chem. 30 (1991) 20242031. 


\section{TABLES CAPTION}

Table 1. Crystal data and structure refinement for $\mathrm{C}_{8} \mathrm{H}_{34} \mathrm{~B}_{18} \mathrm{FeN}$.

Table 2. Details of the crystallographic data collection for dianionic ortho ferrabis(dicarbollide) and monoanionic meta ferrabis(dicarbollide) ligands.

Table 3. Selected Interatomic Distances ( $\mathrm{A})$ between $\mathrm{Fe}-\mathrm{C}$ and $\mathrm{Fe}-\mathrm{B}$ obtained in ferrabis(dicarbollide) anions. 


\section{FIGURE CAPTIONS}

Figure 1. The molecular and crystal structure of $\left[2,2^{\prime}-\mathrm{Fe}\left(1,7-\text { closo- } \mathrm{C}_{2} \mathrm{~B}_{9} \mathrm{H}_{11}\right)_{2}\right]^{-}$showing the atom numbering and displacement. Ellipsoids are at 50\% probability level.

Figure 2. A view of the iron environment in $\left[\mathrm{N}\left(\mathrm{CH}_{3}\right)_{4}\right]\left[2,2^{\prime}-\mathrm{Fe}\left(1,7-\text { closo- } \mathrm{C}_{2} \mathrm{~B}_{9} \mathrm{H}_{11}\right)_{2}\right]$ (a) a $3 \mathrm{D}$ structure(b) a projection planar.

Figure 3. The dnorm and shape index Hirshfeld surfaces and the fingerprint plots of the anion and cation in $\left[\mathrm{N}\left(\mathrm{CH}_{3}\right)_{4}\right]\left[2,2^{\prime}-\mathrm{Fe}\left(1,7-\text { closo- } \mathrm{C}_{2} \mathrm{~B}_{9} \mathrm{H}_{11}\right)_{2}\right]$ crystal.

Figure 4. HS characterization of different H-B vertex from adjacent anion and cation. 
Table 1.

Empirical formula

Formula weight

Temperature

Wavelength

Crystal system

Space group

Unit cell dimensions

Volume

Z

$\rho_{\text {cal }}\left(\mathrm{Mg} / \mathrm{m}^{3}\right)$

Absorption coefficient $\left(\mathrm{mm}^{-1}\right)$

$\mathrm{F}(000)$

Crystal size

Theta range for data collection

Index ranges

Independent reflections

Absorption correction

Max. and min. transmission

Refinement method

$\mathrm{R}_{2}$ int

Final R indices [I>2sigma(I)]

\section{$\mathrm{C}_{8} \mathrm{H}_{34} \mathrm{~B}_{18} \mathrm{FeN}$}

394.79

170(2) K

$0.71073 \AA$

Monoclinic

$\mathrm{C} 2 / \mathrm{c}$

$$
\begin{array}{ll}
\mathrm{a}=22.7723(7) \AA & \alpha=90^{\circ} \\
\mathrm{b}=10.1834(5) \AA & \beta=105.061(2)^{\circ} \\
\mathrm{c}=9.9464(5) \AA & \gamma=90^{\circ} .
\end{array}
$$

\section{3(2) $\AA^{3}$}

4

1.177

0.672

820

$0.205 \times 0.181 \times 0.037 \mathrm{~mm}^{3}$

$2.204^{\circ}$ to $29.167^{\circ}$.

$-31 \leq \mathrm{h} \leq 29,-13 \leq \mathrm{k} \leq 13$,

$-13 \leq \mathrm{l} \leq 13$

2991

Semi-empirical from equivalents

0.7458 and 0.6759

Full-matrix least-squares on $\mathrm{F}^{2}$

0.0492

$$
{ }^{a} R 1=\Sigma|| F_{\mathrm{o}}|-| F_{\mathrm{c}}|/ \Sigma| F_{\mathrm{o}} \mid .{ }^{b} \mathrm{wR} 2=\left[\Sigma \left[w\left(F_{\mathrm{o}}{ }^{2}-F_{\mathrm{c}}{ }^{2}{ }^{2}\right] / \Sigma\left[w\left(F_{\mathrm{o}}{ }^{2}{ }^{2}\right]\right]^{1 / 2} .\right.\right.
$$


Table 2 :

\begin{tabular}{|c|c|c|}
\hline Chemical Formula & $\mathrm{C}_{12} \mathrm{H}_{46} \mathrm{FeB}_{18} \mathrm{~N}_{2}$ & $\mathrm{C}_{8} \mathrm{H}_{34} \mathrm{~B}_{18} \mathrm{FeN}$ \\
\hline Radiation & \multicolumn{2}{|c|}{ Mo K $\alpha$} \\
\hline Wavelength/ $\AA$ & \multicolumn{2}{|c|}{$0.7107 \AA$} \\
\hline Isomer & Ortho & meta \\
\hline Ref & {$[30]$} & our work \\
\hline Solvent & $\mathrm{CH}_{3} \mathrm{CN} /\left(\mathrm{C}_{2} \mathrm{H}_{5}\right)_{2} \mathrm{O}$ & $\left(\mathrm{CH}_{3}\right)_{2} \mathrm{CO}$ \\
\hline Space group & $\mathrm{P} 2{ }_{1} / \mathrm{c}$ & $\mathrm{C} 2 / \mathrm{c}$ \\
\hline $\mathbf{a} / \AA$ & $9.017(3)$ & $22.772(7)$ \\
\hline b/ $\AA$ & $11.341(3)$ & $10.183(5)$ \\
\hline c/ $\AA$ & $32.941(11)$ & $9.946(5)$ \\
\hline$\beta\left({ }^{\circ}\right)$ & $91.80(1)$ & 105.06 \\
\hline $\mathbf{v} / \AA^{3}$ & 1381 & $2227(17)$ \\
\hline $\mathbf{Z}$ & 2 & 4 \\
\hline $\mathbf{R}$ & 0.094 & 0.046 \\
\hline $\mathbf{R w}$ & 0.104 & 0.092 \\
\hline$\rho(\mathrm{cal}) / \mathrm{g} \mathrm{cm}^{-3}$ & 1.13 & 1.17 \\
\hline
\end{tabular}


Table 3.

\begin{tabular}{ll|ll}
\hline \multicolumn{2}{c|}{$\mathbf{F e}\left(\mathbf{2 , 2} \mathbf{2}^{\prime}\right)-\mathbf{1 , 7}-\left(\mathbf{C}_{\mathbf{2}} \mathbf{B}_{\mathbf{1 0}} \mathbf{H}_{\mathbf{1 1}}\right)_{\mathbf{2}}$} & \multicolumn{2}{c}{$\mathbf{F e}(\mathbf{3 , 3})-\mathbf{1 , 2}-\left(\mathbf{C}_{\mathbf{2}} \mathbf{B}_{\mathbf{1 0}} \mathbf{H}_{\mathbf{1 1}}\right)_{\mathbf{2}}$} \\
\hline $\mathrm{Fe}\left(2,2^{\mathrm{a}}\right)-\mathrm{C}(1)$ & $2.083(2)$ & $\mathrm{Fe}(3,3 \mathrm{a})-\mathrm{C}(1)$ & $2.015(8)$ \\
$\mathrm{Fe}\left(2,2^{\mathrm{a}}\right)-\mathrm{C}\left(1^{\mathrm{a}}\right)$ & $2.083(2)$ & $\mathrm{Fe}\left(3,3^{\mathrm{a}}\right)-\mathrm{C}\left(1^{\mathbf{a}}\right)$ & $2.015(8)$ \\
$\mathrm{Fe}\left(2,2^{\mathrm{a}}\right)-\mathrm{B}(3)$ & $2.100(2)$ & $\mathrm{Fe}\left(3,3^{\mathrm{a}}\right)-\mathrm{C}(2)$ & $2.047(8)$ \\
$\mathrm{Fe}\left(2,2^{\mathrm{a}}\right)-\mathrm{B}\left(3^{\mathrm{a}}\right)$ & $2.100(2)$ & $\mathrm{Fe}\left(3,3^{\mathrm{a}}\right)-\mathrm{C}\left(2^{\mathrm{a}}\right)$ & $2.047(8)$ \\
$\mathrm{Fe}\left(2,2^{\mathrm{a}}\right)-\mathrm{B}(6)$ & $2.111(2)$ & $\mathrm{Fe}\left(3,3^{\mathrm{a}}\right)-\mathrm{B}(4)$ & $2.073(10)$ \\
$\mathrm{Fe}\left(2,2^{\mathrm{a}}\right)-\mathrm{B}\left(6^{\mathrm{a}}\right)$ & $2.111(2)$ & $\mathrm{Fe}\left(3,3^{\mathrm{a}}\right)-\mathrm{B}\left(4^{\mathrm{a}}\right)$ & $2.073(10)$ \\
$\mathrm{Fe}\left(2,2^{\mathrm{a}}\right)-\mathrm{C}(7)$ & $2.111(2)$ & $\mathrm{Fe}\left(3,3^{\mathrm{a}}\right)-\mathrm{B}(8)$ & $2.144(10)$ \\
$\mathrm{Fe}\left(2,2^{\mathrm{a}}\right)-\mathrm{C}\left(7^{\mathrm{a}}\right)$ & $2.111(2)$ & $\mathrm{Fe}\left(3,3^{\mathrm{a}}\right)-\mathrm{B}\left(8^{\mathrm{a}}\right)$ & $2.144(10)$ \\
$\mathrm{Fe}\left(2,2^{\mathrm{a}}\right)-\mathrm{B}(11)$ & $2.131(2)$ & $\mathrm{Fe}\left(3,3^{\mathrm{a}}\right)-\mathrm{B}(7)$ & $2.112(10)$ \\
$\mathrm{Fe}\left(2,2^{\mathrm{a}}\right)-\mathrm{B}\left(11^{\mathrm{a}}\right)$ & $2.131(2)$ & $\mathrm{Fe}\left(3,3^{\mathrm{a}}\right)-\mathrm{B}\left(7^{\mathrm{a}}\right)$ & $2.112(10)$ \\
\hline
\end{tabular}




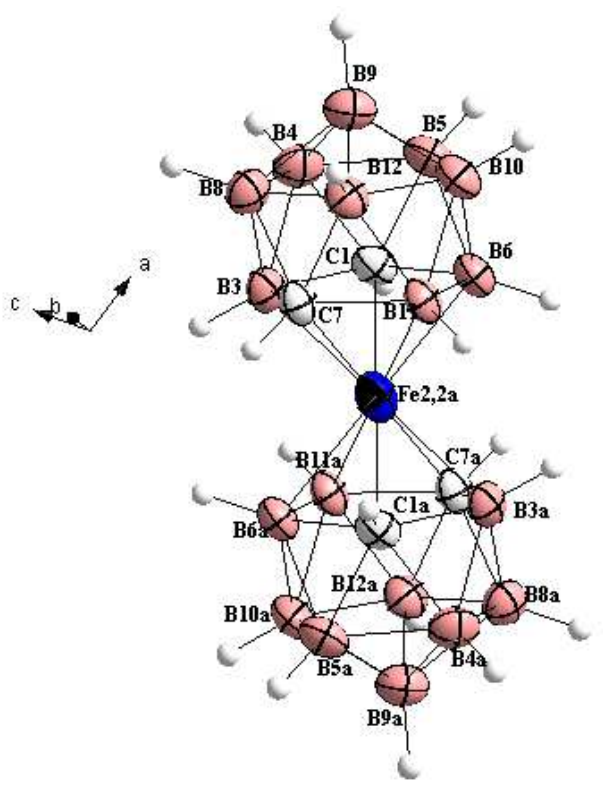

Figure 1:

Symmetry code :

a: 1/2-x, 1/2-y, 1-z 


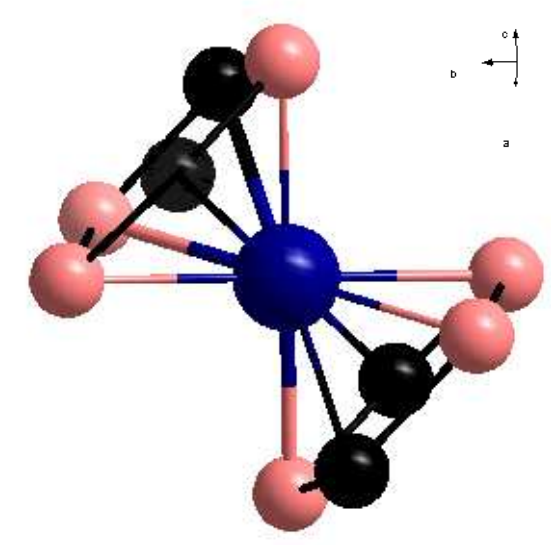

(a)

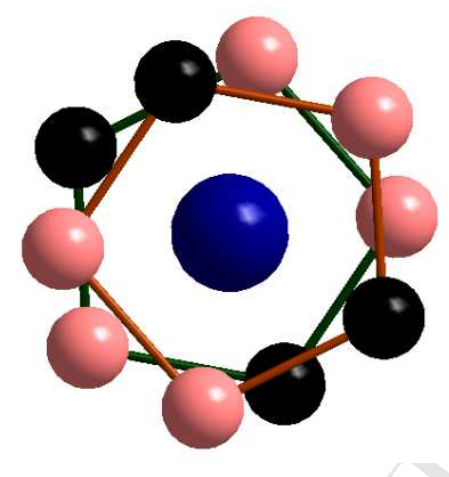

(b)

Figure 2: 


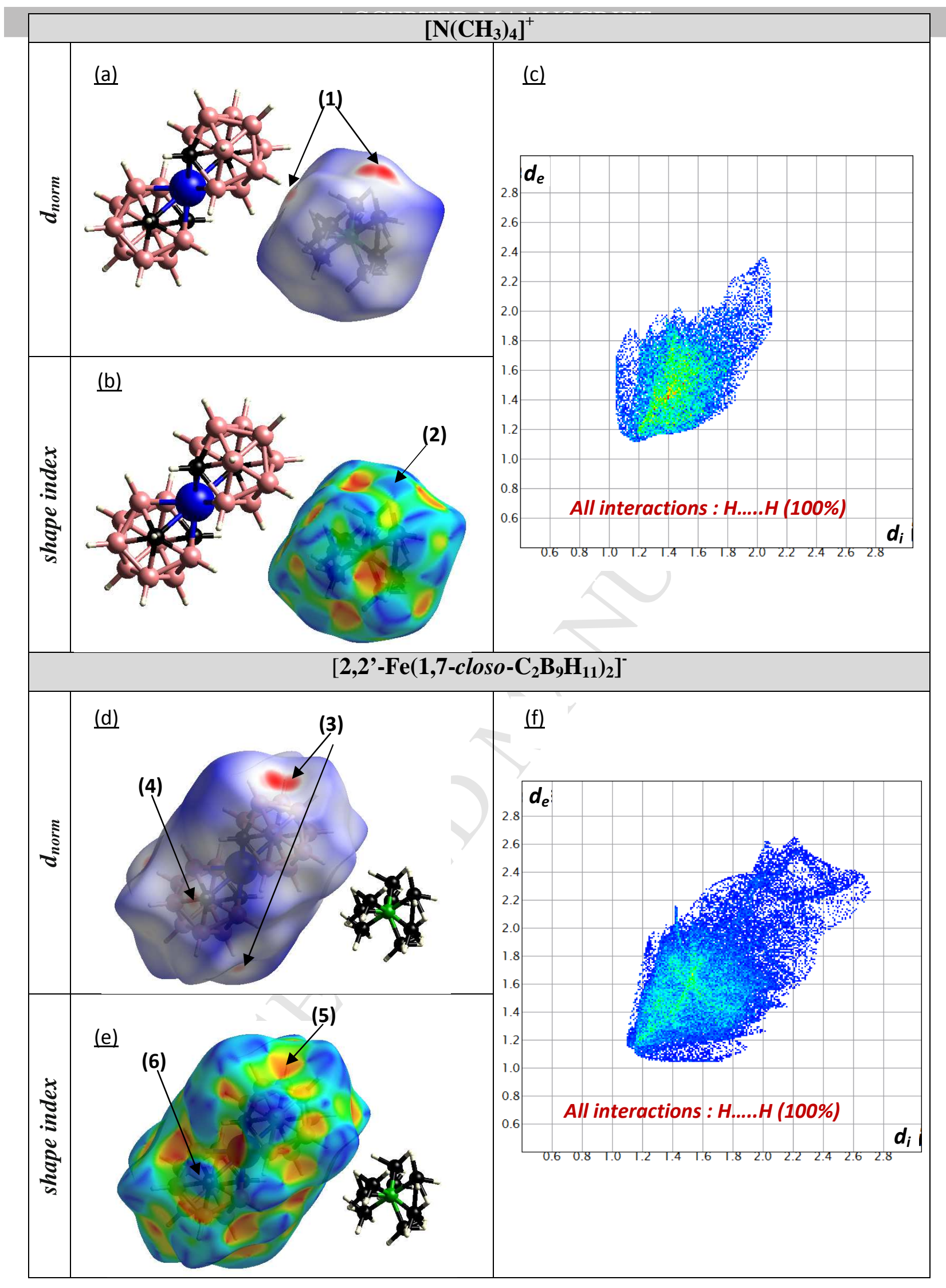

Figure 3. 


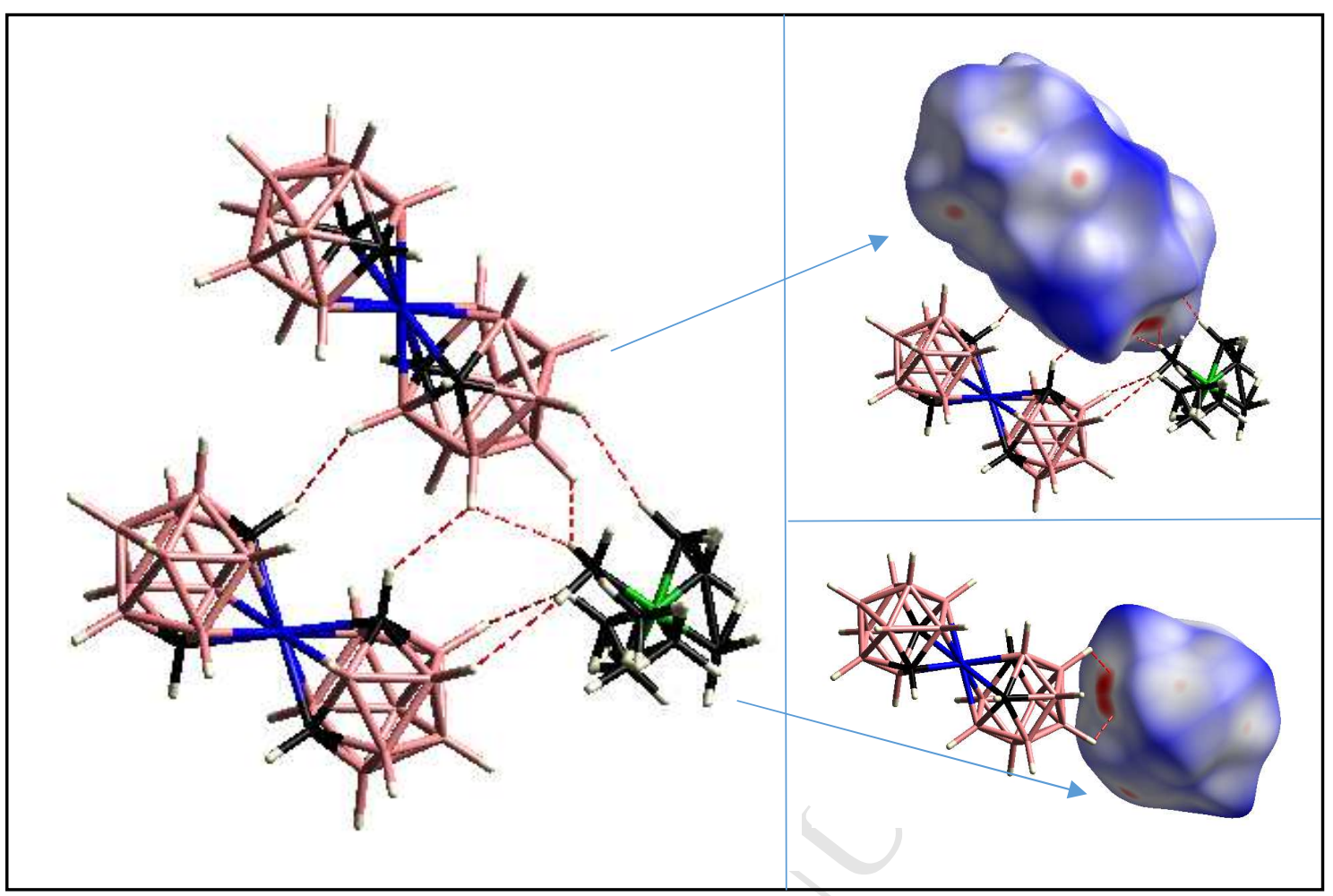

Figure 4. 


\section{$\underline{\text { Highlights }}$}

- The $\left[\mathrm{N}\left(\mathrm{CH}_{3}\right)_{4}\right]\left[2,2^{\prime}\right.$ - $\left.\mathrm{Fe}\left(1,7-\text { closo- } \mathrm{C}_{2} \mathrm{~B}_{9} \mathrm{H}_{11}\right)_{2}\right]$ crystal was solved in a monoclinic system with $\mathrm{C} 2 / \mathrm{c}$ space group.

- The structure of the obtained crystal consisted of discrete [2,2'-Fe(1,7-closo$\left.\left.\mathrm{C}_{2} \mathrm{~B}_{9} \mathrm{H}_{11}\right)_{2}\right]^{-}$anions and disordered $\left[\mathrm{N}\left(\mathrm{CH}_{3}\right)_{4}\right]^{+}$cations.

- Hirshfeld surfaces and fingerprint plot were used to visualize and explore intermolecular interactions in the $\left[\mathrm{N}\left(\mathrm{CH}_{3}\right)_{4}\right]\left[2,2^{\prime}\right.$ - $\left.\mathrm{Fe}\left(1,7 \text {-closo- } \mathrm{C}_{2} \mathrm{~B}_{9} \mathrm{H}_{11}\right)_{2}\right]$ crystal. 